\title{
RENAL PERFORMANCE IN RELATION TO WATER AND NITROGEN METABOLISM IN BEDOUIN GOATS DURING LACTATION
}

\author{
Ephraim Maltz, Nisim Silanikova and Amiram Shkolnik \\ The George S. Wise Center for Life Sciences, Tel Aviv University, Israel
}

(Received 2 February 1981)

\begin{abstract}
Black Bedouin goats $(16-24 \mathrm{~kg}$ body wt) at 4-5 months post partum produce daily in the laboratory $50 \mathrm{~g}$ milk per $\mathrm{kg}$ body wt. Similar yields were recorded at mid-summer in goats herded in the desert where food is meagre, low in protein and water is scarce.

2. Urine concentration in lactating goats was higher than in goats before gestation but urine urea concentration was only a third that in the non-lactating ones. The increase in urine volume in the lactating goats was less pronounced than the increase in drinking and water turnover rates or in food consumption.

3. Daily renal reabsorption of urea in lactating goats amounted to $588 \mathrm{mmol}$ compared to only 361 in non-lactating ones. Urine urea loss in lactating goats was $25 \%$ less than in the non-lactating ones.

4. Urea entry rate in lactating goats was $65 \%$ higher than in non-lactating goats. $748.6 \mathrm{mmol}$ urea were recycled daily in lactating goats compared to only $277 \mathrm{mmol}$ in non-lactating ones.

5. The role the kidney plays in economizing both water and nitrogen metabolism in goats lactating in the desert is assessed and discussed.
\end{abstract}

\section{INTRODUCTION}

Black goats of small body size $(15-25 \mathrm{~kg})$ are herded by Bedouins in the extreme deserts of the Middle East (Shkolnik et al., 1972).

Parturition in the Bedouin goats starts at the end of winter and peak lactation takes place during 2 months post-partum and is timed with the favorable conditions prevailing in the desert during this short period. Milk yield during this period was found to be surprisingly high and averaged $71 \mathrm{~g}(\mathrm{~kg} \cdot \mathrm{day})^{-1}$ (Maltz et al., 1980). The water economy of these goats during peak lactation was studied by Maltz \& Shkolnik (1980).

Bedouin goats continue to produce considerable yields of milk throughout the summer and even 6 months post-partum yields as high as one liter per day were reocrded in the field. During the entire summer the desert vegetation is dry and low in protein and drinking water is available only from widely spaced water holes. The ability to economize both water and nitrogen under these conditions is a major factor in the productive capacity of desert animals.

In this study nitrogen kinetics were studied in the laboratory in lactating Bedouin goats fed on dry alfalfa hay (no concentrates added) and watered once daily. The contribution of the kidney to both the nitrogen metabolism and water economy of these lactating goats was also assessed.

\section{MATERIALS AND METHODS}

Animals and maintenance. A small herd of black goats was purchased from Bedouins in the Eastern Sinai along

Address correspondence to: Professor A. Shkolnik, Department of Zoology, Tel Aviv University, Ramat Aviv, Tel Aviv 69978, Israel. the Gulf of Eilat. The herd was kept and bred in the research Zoo of the Tel Aviv University under continuous veterinary supervision.

Experiments were carried out during mid-summer in the laboratory where conditions of $25 \pm 2 \mathrm{C}$ and $60 \pm 5.1 \mathrm{r}$.h. continuously prevailed. Four lactating goats 4 to 5 months post partum and four non-lactating goats were placed in metabolic cages. Two weeks were allowed for all animals to adjust to the experimental conditions. All goats were $2-4 \mathrm{yr}$ old. Alfalfa hay was fed ad libitum twice a day. Water was offered once daily before the afternoon feeding time. Urine was collected under a iayer of paraffin oil. The kids of lactating goats were kept separated from their mothers but could be heard and seen by them.

Water turnover rates. These were calculated from the rate of disappearance of HTO (Macfarlane et al., 1972; Maltz \& Shkolnik, 1980). $0.5 \mathrm{mCi}$ in $2 \mathrm{ml}$ saline were injected into the jugular vein. Blood plasma was sampled every hour for $6 \mathrm{hr}$ following the injection of the marker. $50 \mu \mathrm{l}$ of plasma for HTO determination were diluted in Insta Gel scintillation liquid (Packard). The decrease in the concentration of the marker during the sampling period was then extrapolated to "zero" time according to which total body water was assessed. For water turnover measurements samples were taken daily at the same hour for 7 days. and tritium activity was measured as described above.

Urea kinetics. This was measured by using $\mathrm{C}^{14}$ labelled urea. To assess urea entry rate, $2-4 \mu \mathrm{Ci}$ per $\mathrm{kg}$ body weight of $\mathrm{C}^{14}$ labelled urea $(55-60 \mathrm{mCi} / \mathrm{mmol}$, Nuclear Research Center, Negev, Israel) was administered in a saline solution through a Teflon catheter inserted into the jugular vein. Blood was sampled over a period of $9 \mathrm{hr}$ following the injection of the marker. During the first $3 \mathrm{hr}$ it was withdrawn every $30 \mathrm{~min}$ and then once every $60 \mathrm{~min} . \mathrm{C}^{14}$ activity was measured in a liquid scintillation counter.

Urea pool was calculated employing the dilution method and urea entry rate was calculated from the rate at which $\mathrm{C}^{\mathbf{1 4}}$ disappeared (according to the method suggested by Zilversmith, 1960; Cocimano \& Lang, 1967). Recycling of urea was determined by subtracting the rate at which urea was eliminated in the urine from the urea entry rate. Urea 
Table 1. Milk production water turnover and drinking rates and food consumption in 4 black Bedouin goats during lactation and before gestation $(\bar{X} \pm S D)$

\begin{tabular}{ccccc}
\hline $\begin{array}{c}\text { Body weight } \\
(\mathrm{kg})\end{array}$ & $\begin{array}{c}\text { Milk yield } \\
\left(\mathrm{g} \cdot \mathrm{day}^{-1}\right)\end{array}$ & $\begin{array}{c}\text { WTO } \\
\left(\mathrm{ml} \cdot \mathrm{day}^{-1}\right)\end{array}$ & $\begin{array}{c}\text { Drinking } \\
\text { volume } \\
\left(\mathrm{ml} \cdot \mathrm{day}^{-1}\right)\end{array}$ & $\begin{array}{c}\text { Food } \\
\text { consumption } \\
\left(\mathrm{g}(\mathrm{DM}) \cdot \text { day }^{-1}\right)\end{array}$ \\
\hline $22.0 \pm 2.1$ & $933 \pm 184$ & $\begin{array}{c}\text { Lactating } \\
3388 \pm 525\end{array}$ & $2720 \pm 482$ & $906 \pm 162$ \\
\hline $17.4 \pm 2.8$ & & $\begin{array}{c}\text { Non-lactating } \\
1474 \pm 91\end{array}$ & $931 \pm 47$ & $480 \pm 45$ \\
\hline
\end{tabular}

concentration in plasma and urine was determined colorimetrically following treatment with diacetylmonoxime according to Foster \& Hochholzer (1971).

Osmotic concentration. This was measured by Fiske Osmotic Automatic Osmometer (Model 130).

Electrolyte concentration. $\mathrm{Na}^{+}$and $\mathrm{K}^{+}$were measured by atomic absorption spectrophotometer, Unicom SP-90. $\mathrm{Cl}^{-}$was measured by Chlorid titrator CMT 10 Radiometer.

Glomerular filtration rate $(G F R)$. This was measured as the clearance rate of endogenous creatinine. Blood plasma samples for creatinine determination were withdrawn several times a day and urine was collected and sampled whenever voided. Creatinine concentration was determined by a modification of Jaffe reaction (Hare, 1950) employing Loids Reagent.

\section{RESULTS}

Following peak lactation Bedouin goats in the laboratory produced milk for over 6 months. Four months post-partum their daily yield amounted to $50 \mathrm{~g}$ $(\mathrm{kg} \cdot \mathrm{day})^{-1}$. During this time both their food consumption and water requirements were considerably higher than the values recorded in goats before gestation (Table 1). Water turnover rates in these lactating goats amounted to $154 \mathrm{ml}(\mathrm{kg} \cdot \mathrm{day})^{-1}$ compared to $86 \mathrm{ml}\left(\mathrm{kg} \cdot\right.$ day) ${ }^{-1}$, in non-lactating goats (Table 1).

Urinc volume in the lactating goats was $60 \%$ higher than in the non-lactating ones. No difference in GFR was recorded (Table 2). Urine concentration was considerably higher in the lactating goats but their urine urea concentration was much lower than that of nonlactating ones (Fig. 1).

Blood plasma concentration was slightly though significantly lower in the lactating goats and the U/P ratio amounted to 7.5 in the lactating goats compared to only 5.7 in the non-lactating ones.

Nitrogen kinetics are summarized in Table 3. In agreement with the high food consumption of the lactating goats (Table 1) their nitrogen intake amounted to twice the value recorded in the non-lactating ani-

Table 2, Glomerular filtration rate (GFR) and urine volume $\left(1 \cdot\right.$ day $\left.^{-1}\right)$ in 4 black Bedouin goats during lactation and before gestation $(X \pm S D)$

\begin{tabular}{cc}
\hline GFR & Urine volume \\
\hline $85.8 \pm 23.0$ & $0.654 \pm 0.127$ \\
\hline \multicolumn{3}{c}{ Lactating } \\
\hline Non-lactating \\
\hline
\end{tabular}

mals. Urea entry rate was higher $(65 \%)$ and urinary urea loss was lower $(25 \%)$ in lactating than in nonlactating goats. The lactating goats recycled daily through their gut for microbiol resynthesis of proteins and amino acids $748.6 \mathrm{mmol}$ urea compared to only $277 \mathrm{mmol}$ recycled daily by non-lactating goats.

\section{DISCUSSION}

Compared to the rates of water turnover, water and food intake which were all twice as high in the lactating than in the non-lactating goats, urine volume of the lactating goats was higher by only 1.6. The high $U / P$ ratio recorded in the lactating goats results mainly from their high urine osmotic concentration. However, a slight drop in their blood plasma concentration also contributes to it. A low blood plasma osmotic concentration seems to be related to the outstandingly large Evans-Blue space that was described in lactating goats by Maltz \& Shkolnik (1980). The relatively small increase in urine volume and the increase in the urine osmotic concentration - both are

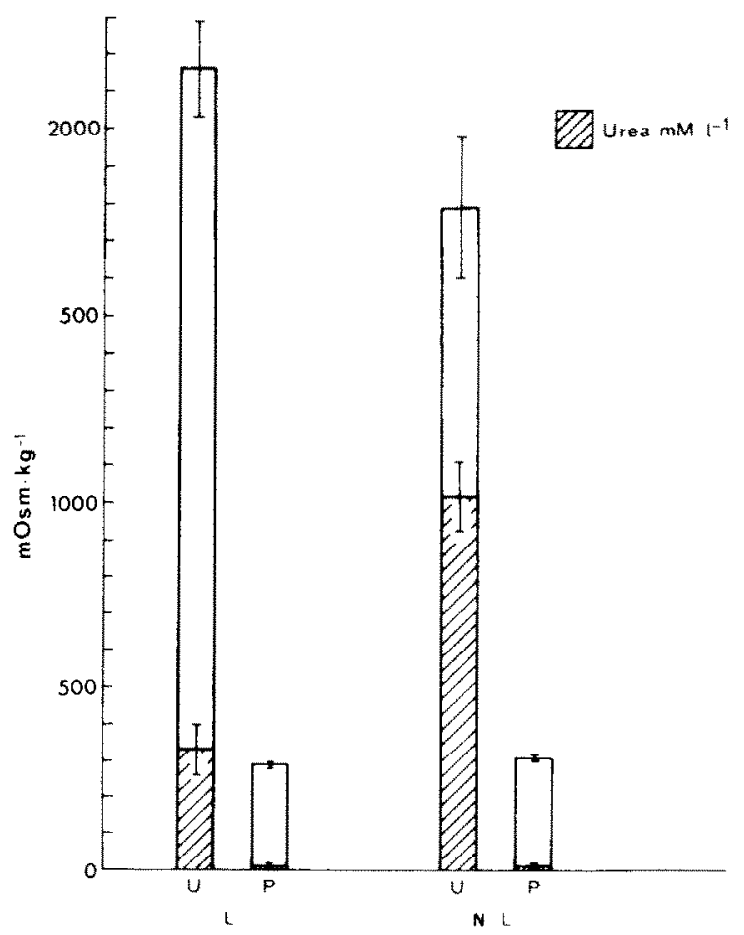

Fig. 1. Osmotic and urea concentration in urine (u) and blood plasma (p) of 4 lactating (L) and 4 non-lactating (NL) black Bedouin goats. 
Table 3. Nitrogen kinetics in 4 black Bedouin goats during lactation and before gestation $(\overline{\mathrm{X}} \pm \mathrm{SD})$

\begin{tabular}{|c|c|c|c|c|c|c|}
\hline $\begin{array}{l}N \text { intake } \\
\left(\mathrm{g} \cdot \text { day }^{-1}\right)\end{array}$ & $\begin{array}{c}\text { N urea body } \\
\text { pool } \\
(\mathrm{g})\end{array}$ & $\begin{array}{c}N \text { urea entry } \\
\text { rate } \\
\left(\mathrm{g} \cdot \text { day }^{-1}\right)\end{array}$ & $\begin{array}{l}N \text { urine urea } \\
\left(\mathrm{g} \cdot \mathrm{day}^{-1}\right)\end{array}$ & $\begin{array}{l}N \text { milk urea } \\
\left(\mathrm{g} \cdot \text { day }^{-1}\right)\end{array}$ & $\begin{array}{l}N \text { recycled urea } \\
\left(\mathrm{g} \cdot \text { day }^{-1}\right)\end{array}$ & $\begin{array}{l}N \text { urea recycled } \\
(\% \text { of entry rate })\end{array}$ \\
\hline $27.11 \pm 4.15$ & $4.876 \pm 0.918$ & $28.310 \pm 4.737$ & $\begin{array}{c}\text { Lactating } \\
7.250 \pm 2.143\end{array}$ & $0.249 \pm 0.052$ & $20.812 \pm 6.471$ & 73.51 \\
\hline $13.60 \pm 2.12$ & $2.973 \pm 0.205$ & $17.314 \pm 1.287$ & $\begin{array}{l}\text { Non-lactating } \\
9.593 \pm 0.585\end{array}$ & - & $7.721 \pm 0.585$ & 44.59 \\
\hline
\end{tabular}

the renal contributions to water conservation in lactating goats.

The demands of milk production on the nitrogen economy are met not only by the twofold increase in protein consumed but also by the threefold increase in the urea recycling rate: the recycled urea in the lactating goats amounts to $73 \%$ of their urea entry rate compared to $45 \%$ in the non-lactating goats. The capacity of the black Bedouin goat to economize its nitrogen metabolism has already been described by Silanikove et al. (1980). When fed wheat straw they recycled $90 \%$ of the urea entering their circulation. This capacity was interpreted as an adaptation that helps them to exploit desert pasture which is often dry and low in protein. A similar interpretation of such a capacity was suggested for the camel by SchmidtNielsen et al. (1957).

Renal conservation of urea is essential for the maintenance of a high recycling rate. Urine urea concentration in lactating goats is indeed only one third of the concentration found in non-lactating goats. Although $805.2 \mathrm{mmol}$ urea are filtrated daily in the kidney of the lactating goats compared to $761.0 \mathrm{mmol}$ in the non-lactating ones, only $217.3 \mathrm{mmol} \mathrm{day}^{-1}$ are lost in the urine of the lactating goats compared to $399.8 \mathrm{mmol}$ in nonlactating ones. Recycling urea instead of voiding it decreases the osmotic load on the kidney and helps to reduce urinary volume. If the recycling rate of lactating goats remained at the level of non-lactating goats, the lactating animals would have to excrete about $500 \mathrm{mmol}$ more urea in their urine. Even when assuming a urinary urea concentration as high as those recorded in non-lactating goats this excretion would demand an additional $600 \mathrm{ml}$ of water per day. Thus the kidney in lactating goats contributes to both the nitrogen and water economy of these animals and the two contributions are complementary to each other.

Acknowledgement-This study was partly supported by the International Atomic Energy Agency, Vienna.

\section{REFERENCES}

Cocimano M. R. \& Lang R. A. (1967) Metabolism of urea in sheep. Br. J. Nutr. 21, 353-371.

FOSTER L. B. \& HochHolzer J. M. (1971) A single reagent manual method for directly determining urea nitrogen in serum. Clin. Chem. 17, 921-925.

HARE R. S. (1950) Endogenous creatinine in serum and urine. Proc. Soc. exp. Biol. Med. 74, 148.

Macfarlane W. V., Howard B., Maloly G. M. O. \& HOPCRAFT D. (1972) Tritiated water in field studies of ruminant metabolism in Africa. In Isotope studies on the physiology of domestic animals (Edited by MACFARLANE W. V.), pp. 83-94. International Atomic Energy Agency, Vienna.

Maltz E., Shkolnik A. \& Gordin S. (1980) Lactation in the black Bedouin goat. II. Productivity and milk properties. $J$. Dairy $S c i$. In press.

Maltz E. \& ShKolniK A. (1980) Milk production in the desert: Lactation and water economy in the black Bedouin goat. Physiol. Zool. 53, 12-18.

SChmidt-Nielsen B., Schmidt-Nielsen K., Houpt T. R. \& JARNum S. W. (1957) Urea excretion in camels. $A m$. $J$. Physiol. 188, 477-484.

ShKolNiK A., Borut A. \& ChoshniaK I. (1972) Water economy of the Bedouin goat. Symp. zool. Soc. Lond. 31, 229-242.

Silanikove N., Tagari H. \& Shrolnik A. (1980) Gross energy digestion and urea recycling in the desert black Bedouin goat. Comp. Biochem. Physiol. 67A, 215-218.

ZILVERSMITH D. B. (1960) The design and analysis of isotope experiments. Am. J. Med. 29, 823-848. 